\title{
Ocena 20-letnich wyników leczenia i czynników prognostycznych u chorych na raka piersi po mastektomii radykalnej i radioterapii pooperacyjnej
}

\author{
Jacek Gałecki ${ }^{1}$, Marta Olszyna-Serementa ${ }^{1}$, Wojciech Michalski ${ }^{2}$
}

\begin{abstract}
Wstęp. W ostatnich 20 latach nastąpił znaczny postęp w diagnostyce i leczeniu chorych na raka piersi. Do leczenia uzupełniającego wprowadzono antracykliny i taksany (AT). Celem pracy jest ocena wyników leczenia chorych po radykalnej mastektomii i radioterapii pooperacyjnej przed erą AT. Oceniono częstość występowania późnych powikłań leczenia.
\end{abstract}

Materiał i metody. Analizą retrospektywną objęto 470 kolejnych kobiet chorych na raka piersi w stopniach I-III B po mastektomii radykalnej, napromienianych w Centrum Onkologii w latach 1985-1994. Mediana wieku wynosiła 56 lat (przedział: 26-77). Przerzuty w węzłach chłonnych pachowych po operacji (pN1-2) rozpoznano u 80\%, a u pozostałych 20\% przerzutów nie stwierdzono (pN0). Chemioterapię według programu CMF lub Ansfielda zastosowano u 32\%, a hormonoterapię tamoksyfenem u 39\% chorych. Mediana obserwacji dla chorych żyjących wynosiła 17,5 roku. Krzywe przeżycia całkowitego (PC) i bezobjawowego (PB) obliczano metodą Kaplana-Meiera, do analizy czynników rokowniczych zastosowano model proporcjonalnego ryzyka Coxa. Do oszacowania funkcji skumulowanego odsetka nawrotów lokoregionalnych (SONLR) zastosowano metodę wydarzeń konkurujących (CRM - competing risks method). Wyniki. 10- i 20-letnie PB i PC chorych wynosiły odpowiednio: 32\% i 19\%; 40\% i 24\%. 10- i 20-letni SONLR oraz konkurujących wydarzeń: przerzutów odległych, zgonów z nieustalonej przyczyny, raka drugiej piersi, innego nowotworu złośliwego wyniosły odpowiednio: 21\% i 21\%; 36\% i 40\%; 7,3\% i 11,3\%; 3,2\% i 4,7\%; 1,3\% i 1,8\%. W ciągu pierwszych 5 lat pojawiło się $69 \%$, w ciągu 10 lat $86 \%$, a po 10 latach $14 \%$ nawrotów raka piersi. Potwierdzono, że najsilniejszym czynnikiem wpływającym zarówno na ryzyko nawrotu, jak i zgonu była liczba zajętych przez przerzuty węzłów chłonnych, usuniętych podczas mastektomii radykalnej — powyżej trzech $(p=0,0001)$. Nie wykazano podobnej różnicy w grupie chorych z pN0 vs pN1-3 ( $p>0,18$ ). Z późnych powikłań związanych z leczeniem rozpoznano: obrzęk kończyny górnej u 13,6\% chorych i porażenie splotu barkowego u 0,9\% chorych. U jednej chorej po 19 latach od napromieniania rozpoznano, w obszarze spadku dawki, płaskonabłonkowego raka płuca.

Wnioski. 1.Z dzisiejszego punktu widzenia uzyskane odległe wyniki leczenia chorych na raka piersi napromienianych po mastektomii świadczą o małej skuteczności ówczesnego leczenia. 2. Pięcioletni okres obserwacji chorych na raka piersi jest zbyt krótki do oceny wyników leczenia, gdyż nawet po 10 latach ryzyko nawrotu lub zgonu z powodu raka piersi jest wysokie.

\section{Treatment results at $\mathbf{2 0}$ years and prognostic factors in post-mastectomy irradiated breast} cancer patients

Introduction. In the last 20 years, anthracycline and taxanes (AT) have been implemented in breast cancer treatment. The aim of this work is to estimate the prognostic factors and long-term disease-free survival in breast cancer patients after radical mastectomy and postoperative radiotherapy before implementation of AT.

\footnotetext{
${ }^{1}$ Zakład Teleradioterapii

${ }^{2}$ Pracownia Biostatystyki

Centrum Onkologii — Instytut im. Marii Skłodowskiej-Curie w Warszawie
} 
Material and methods. The retrospective analysis included 470 post-mastectomy breast cancer patients in stage I-IIIB consecutively irradiated in the Cancer Center and Institute of Oncology in Warsaw from 1985 to 1994. The women were aged 26-77 years with a median of 56 years, and there were $80 \%$ with pN1-2 stage, and $20 \%$ with pN0. Simultaneously with radiotherapy $32 \%$ of patients received chemotherapy (CMF and/or Ansfield'a regimen) and 39\% hormonotherapy (Tamoxifen). The median follow-up was 17.5 years. Disease free survival (DFS) and overall survival (OS) were analyzed by the Kaplan-Meier method, and prognostic factors were studied using the Cox's proportional hazards regression model. To assess the function of the cumulative percentage of loco-regional recurrences (CPLRR) the competing risk method was used.

Results. 10-and 20-year DFS and OS rates were respectively 32\% and 19\%; 40\% and 24\%. 10-year and 20-year CPLRR rates and competing events: distant metastases, deaths from unknown causes, cancer of the second breast and other malignant tumours were respectively: $21 \%$ and $21 \% ; 36 \%$ and $40 \% ; 7.3 \%$ and $11.3 \% ; 3.2 \%$ and $4.7 \% ; 1.3 \%$ and $1.8 \%$. Within the first 5 years, $69 \%$, in 10 years $86 \%$, and after 10 years $14 \%$ of breast cancer failures occurred. It was confirmed, that the strongest prognostic factor influencing both the DFS and OS was the number of involved axillary lymph nodes - above three $(p=0.0001)$. There were no statistically significant differences in the groups of patients with pN0 vs pN1-3 in both PB and PC. The presence of lymphoedema of the upper extremity and brachial plexopathy was correlated with post-mastectomy radiotherapy in $13.6 \%$ and $0.9 \%$ of patients. In one patient after 19 years of irradiation, squamous cell lung cancer was diagnosed in an area of low dose.

Conclusions. Post-mastectomy treatment resulted in a not very satisfactory survival of breast cancer patients. The 5-year follow-up period for breast cancer patients is too short to assess the results of the treatment, because even after 10 years the probability of recurrence or death due to breast cancer is high.

NOWOTWORY Journal of Oncology 2014; 64, 4: 297-303

Słowa kluczowe: rak piersi, radioterapia po mastektomii, odległe wyniki leczenia

Key words: breast cancer, post-mastectomy treatment, long-term survival

\section{Wstęp}

W ostatnich 20 latach nastąpił znaczny postęp w diagnostyce i w leczeniu chorych na raka piersi. Wprowadzono do leczenia uzupełniającego antracykliny i taksany (AT). W Polsce pomimo wzrostu zachorowań spada umieralność z powodu raka piersi. Jest on jednak najczęstszym nowotworem złośliwym u kobiet i stanowi drugą przyczynę zgonów z powodu nowotworów. Odpowiednie wskaźniki struktury wynoszą 22,4\% i 12,8\% [1, 2]. W Polsce zmieniła się struktura zaawansowania choroby raka piersi. W latach osiemdziesiątych przypadki zaawansowane stanowiły około 70\%, a wczesne około 30\%. Obecnie wzrastająca społeczna świadomość onkologiczna i częstsza profilaktyczna mammografia spowodowały, że proporcje te uległy odwróceniu. Celem pracy jest ocena 20-letnich wyników leczenia chorych po radykalnej mastektomii i radioterapii pooperacyjnej przed erą AT. Zbadano przeżycie bezobjawowe (PB) i całkowite $(P C)$ z uwzględnieniem czynników prognostycznych. Obliczono odsetek niepowodzeń lokoregionalnych na tle innych konkurujących wydarzeń. Oceniono częstość występowania późnych powikłań leczenia.

\section{Materiał i metody}

Analizą retrospektywną objęto 470 kolejnych kobiet chorych na raka piersi po mastektomii radykalnej, napromienianych w Centrum Onkologii w latach 1985-1994. Ma- stektomie radykalne wykonywane były w rejonowych oddziałach chirurgicznych. Najmłodsza chora miała 26 lat, najstarsza - 77 lat, mediana wieku wynosiła 56 lat. W okresie przedmenopauzalnym było 148(32\%), w pomenopauzalnym 322 (68\%) chorych. W analizowanej grupie ustalono następujące stopnie zaawansowania: $1^{0},\left\|0^{0} \mathrm{~A},\right\|{ }^{0} \mathrm{~B},\left\|I^{0} \mathrm{~A},\right\| I^{0} \mathrm{~B}$ odpowiednio u: 17 (4\%), 101 (21\%), 224 (48\%), 20 (4\%), 108 (23\%) chorych. Przerzuty w węzłach chłonnych pachowych po operacji (pN1-2) rozpoznano u 80\%, u pozostałych $20 \%$ chorych nie stwierdzono przerzutów w węzłach chłonnych (pNo) - tabela I. Chemioterapię pooperacyjną według programu CMF (cyclophosphamide, methotrexate, 5-fluorouracil) zastosowano u 151 (32\%) chorych, w tym u $31(6,5 \%)$ chorych w III stopniu zaawansowania operację poprzedzono chemioterapią według schematu Ansfielda (5-fluorouracil, methotrexate, vincristine, cyclophosphamide, encorton), kontynuując program CMF po mastektomii. U 182 (39\%) kobiet podawano przez okres od 3 do 5 lat hormonoterapię pooperacyjną — tamoksyfen. Bez leczenia systemowego pozostało 137 (29\%) chorych. Napromienianie stosowano jednoczasowo z chemioterapią. Radioterapia pooperacyjna polegała na napromienianiu obszaru węzłów chłonnych nad- i podobojczykowych, pachowych i zamostkowych techniką 2D, wiązką promieniowania gamma Co-60 do dawki całkowitej 50 Gy obliczanej w maksimum dawki, podawanej w 25 frakcjach w czasie 5 tygodni. Obszar 
Tabela I. Charakterystyka 470 chorych na raka piersi

\begin{tabular}{|c|c|}
\hline Czynniki & n (\%) \\
\hline \multicolumn{2}{|l|}{ Wiek: } \\
\hline$<50$ roku & $148(32)$ \\
\hline$>50$ roku & $322(68)$ \\
\hline \multicolumn{2}{|l|}{ Pierś: } \\
\hline prawa & $230(49)$ \\
\hline lewa & $240(51)$ \\
\hline \multicolumn{2}{|l|}{ Lokalizacja: } \\
\hline raka w piersi & $64(14)$ \\
\hline kwadranty przyśrodkowe & $406(86)$ \\
\hline \multicolumn{2}{|l|}{ inne } \\
\hline pT1 & $71(15)$ \\
\hline pT2 & $264(56)$ \\
\hline pT3 & $27(6)$ \\
\hline pT4 & $108(23)$ \\
\hline pNo & $94(20)$ \\
\hline pN1 - 1-3 & $180(38)$ \\
\hline $\mathrm{pN} 2-4-8$ & $128(27)$ \\
\hline $\mathrm{pN} 3-\geq 9$ & $68(15)$ \\
\hline \multicolumn{2}{|l|}{ Mediana usuwanych węzłów = 9} \\
\hline $1^{0}$ & $17(4)$ \\
\hline${ }^{0} \mathrm{~A}$ & $101(21)$ \\
\hline${ }^{0} \mathrm{~B}$ & $224(48)$ \\
\hline$I I I^{0} \mathrm{~A}$ & $20(4)$ \\
\hline$I I I^{0} \mathrm{~B}$ & $108(23)$ \\
\hline \multicolumn{2}{|l|}{ Typy raka inwazyjnego: } \\
\hline carcinoma ductale & $302(64)$ \\
\hline carcinoma lobulare & $137(29)$ \\
\hline dobrze rokujące & $31(7)$ \\
\hline G 1 & $15(3)$ \\
\hline $\mathrm{G} 2$ & $218(47)$ \\
\hline G3 & $91(19)$ \\
\hline Nie ustalono & $146(31)$ \\
\hline \multicolumn{2}{|l|}{ Leczenie systemowe: } \\
\hline chemioterapia & $151(32)$ \\
\hline hormonoterapia & $182(39)$ \\
\hline nie stosowano & $137(29)$ \\
\hline
\end{tabular}

ściany klatki piersiowej napromieniano techniką 3D, wiązką elektronów z indywidualnie dobieraną energią i bolusem do dawki całkowitej 46 Gy obliczanej w izodozie $90 \%$, podawanej w 23 frakcjach w czasie 4,5 tygodnia.

Średni czas od mastektomii do rozpoczęcia napromieniania wynosił 10 tygodni. Obserwacje chorych zamknięto 31 grudnia 2010 roku. Mediana obserwacji dla chorych żyjących wynosiła 17,5 roku. W czasie obserwacji zmarło $344 / 470$ (73\%) chorych, w tym 279 (59\%) z powodu nawrotu raka piersi. Dziewięć chorych (2\%) zmarło z powodu innych nowotworów złośliwych: rak żołądka (2 chore), rak płuca (2 chore), rak macicy (2 chore), rak jajnika (2 chore), rak nerki (1 chora). U jednej chorej przyczyną zgonu był zawał serca. Przyczyny zgonu nie udało się ustalić dla 54 (11,5\%) chorych, a informację o zgonie uzyskano z Samodzielnej Pracowni Warszawskiego Rejestru Nowotworów. Sto pięć (22\%) leczonych kobiet żyje bez nawrotu, a 21 (4,5\%) żyje z objawami raka piersi.

\section{Metody statystyczne}

Analizowano skuteczność i powikłania leczenia. Do opisu materiału zastosowano standardowe narzędzia statystyki opisowej: tabele częstości dla zmiennych kategorycznych oraz dla zmiennych ciągłych o rozkładzie normalnym: wartość średnią, odchylenie standardowe oraz wartości ekstremalne. Za kryterium oceny skuteczności przyjęto czas PC, liczony od operacji do zgonu z jakiegokolwiek powodu, oraz czas PB, mierzony od operacji do pierwszego niepowodzenia: nawrotu lokoregionalnego, przerzutu odległego lub zgonu z innej przyczyny. Czas przeżycia obliczano metodą Kaplana-Meiera. Potencjalny wpływ wybranych czynników na skuteczność leczenia analizowano, korzystając z modelu proporcjonalnego ryzyka Coxa. Zmienne uwzględnione w modelu: wiek chorej $(<35,36-50$, 51-70, > 70), pierś (prawa/lewa), lokalizacja guza w piersi (część przyśrodkowa vs inne), pT, liczba zajętych przez przerzuty węzłów chłonnych $(0,1-3,4-9,>9)$, stopień histopatologicznej złośliwości G (G1, G2, G3, Gx), inwazja naczyń, naciek brodawki. Model dopasowano metodą krokowej eliminacji zmiennych, z wykorzystaniem w każdym kroku maksymalnego zbioru danych, dla warunków włączenia i wyłączenia odpowiednio: $p=0,05$ i $p=0,1$. Założenie proporcjonalności ryzyka weryfikowano metodą graficzną. Jako miarę skuteczności lokoregionalnej przyjęto skumulowany odsetek nawrotów lokoregionalnych — SONLR (samodzielnych i/lub z rozpoznanymi w czasie 3 miesięcy przerzutami odległymi). Do oszacowania funkcji SONLR (CIF - cumulative incidence function) zastosowano metodę konkurujących ryzyk (CRM - competing risks method), przyjmując nawrót lokoregionalny jako wydarzenie, a przerzut odległy, rak drugiej piersi, inny nowotwór złośliwy oraz zgon z nieznanych przyczyn - jako wydarzenia konkurujące $[3,4]$.

\section{Wyniki}

W ciągu pierwszych 5 lat pojawiło się 69\%, 10 lat - 86\%, a po 10 latach - 14\% nawrotów raka piersi. 10-letnie i 20 -letnie przeżycia bezobjawowe i całkowite leczonych chorych wynosiły odpowiednio: $32 \%$ i $19 \%$; $40 \%$ i $24 \%$ — rycina $1-2$, tabela II. Nawroty lokoregionalne stwierdzono u 101 (21,5\%) chorych, w tym u 51 (10,9\%) rozpoznano je jako samodzielne, a u 50 (10,6\%) chorych — z towarzyszącym przerzutem odległym. Dziesięcioletni skumulowany odsetek nawrotów 


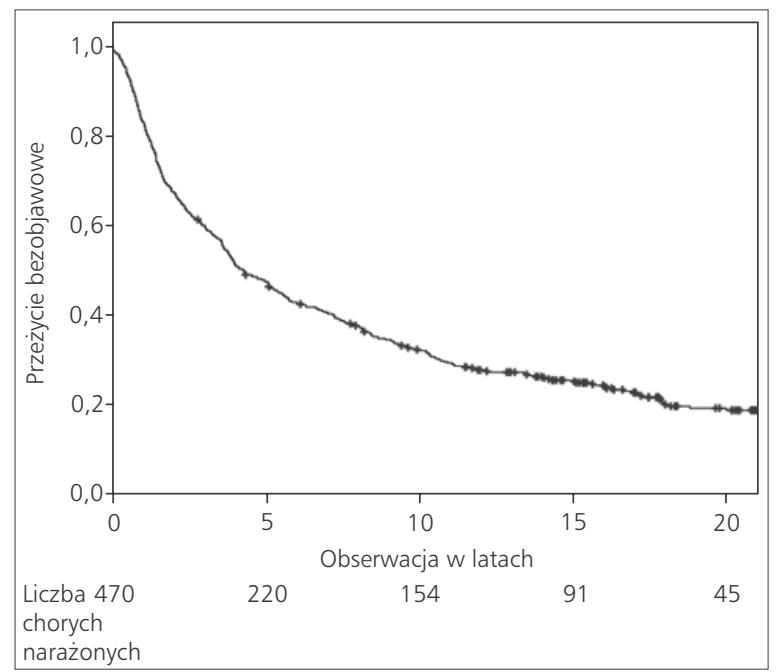

Rycina 1. Przeżycie bezobjawowe 470 chorych na raka piersi napromienianych po mastektomii

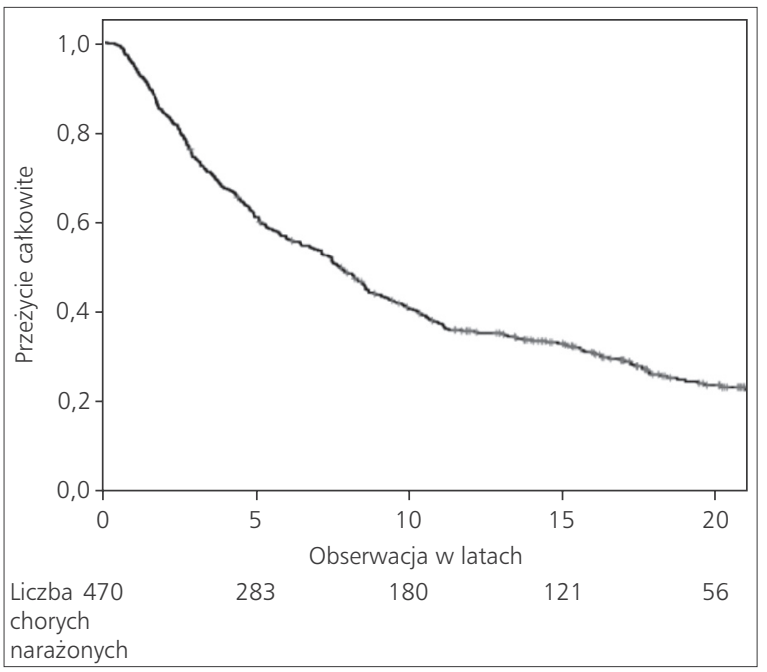

Rycina 2. Przeżycie całkowite 470 chorych na raka piersi napromienianych po mastektomii

lokoregionalnych (SONLR) wraz z 95-procentowym przedziałem ufności wyniósł $21 \%(0,17 ; 0,24)$ i przez pozostały czas obserwacji pozostawał na tym poziomie. Skumulowany odsetek z 95-procentowym przedziałem ufności dla zdarzeń konkurujących: przerzutów odległych, zgonów z nieustalonej przyczyny, raka drugiej piersi i innego nowotworu złośliwego dla dziesięciu i dwudziestu lat obserwacji wyniósł

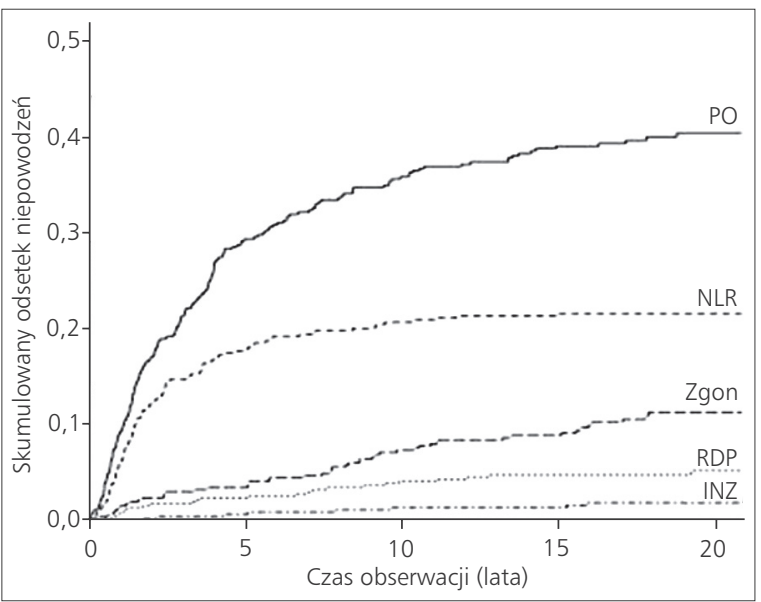

Rycina 3. Skumulowane ryzyko niepowodzeń wśród 470 chorych na raka piersi napromienianych po mastektomii. PO — przerzuty odległe; NLR - nawroty lokoregionalne; Zgon — zgon z nieustalonej przyczyny; RDP — rak drugiej piersi; INZ — inny nowotwór złośliwy

odpowiednio: $36 \%(0,31 ; 0,40)$ i $40 \%(0,36 ; 0,45) ; 7,3 \%(0,05$; $0,09)$ i $11,3 \%(0,08 ; 0,14) ; 3,2 \%(0,02 ; 0,06)$ i $4,7 \%(0,03 ; 0,07)$; $1,3 \%(0,003 ; 0,023)$ i $1,8 \%(0,005 ; 0,031)$ - rycina 3 .

Analiza czynników prognostycznych potwierdziła większe ryzyko nawrotu lub zgonu z powodu raka piersi u chorych z rakiem zrazikowym lub przewodowym w porównaniu z chorymi z rozpoznaniem tzw. typów histopatologicznych dobrze rokujących — tabela III i IV. Najsilniejszym negatywnym czynnikiem prognostycznym, wpływającym zarówno na ryzyko nawrotu raka piersi, jak i zgonu z powodu raka piersi, była liczba zajętych przez przerzuty węzłów chłonnych usuniętych podczas mastektomii radykalnej - powyżej trzech ( $p=0,0001)$. Interesującym jest fakt, że w skonstruowanym modelu statystycznym nie stwierdzono statystycznie istotnych różnic zarówno dla funkcji ryzyka nawrotu, jak i zgonu w grupie chorych z pN0 vs pN1-3 ( $p=0,19$ i $p=0,51)$. Wśród badanych czynników prognostycznych okazało się, że wpływ na ryzyko zgonu z powodu raka piersi miała stwierdzana w badaniu mikroskopowym cecha naciekania brodawki piersi ( $p=0,02$; ryzyko względne: 1,59).

Z późnych poważnych powikłań związanych z przebytym leczeniem stwierdzono: obrzęk kończyny górnej w stopniu 2 lub 3 u 64 (13,6\%) chorych i porażenie splotu barkowego u 4 (0,9\%) chorych. U jednej chorej po 19 latach od napromieniania rozpoznano, w obszarze spadku dawki, płaskonabłonkowego raka płuca.

Tabela II. Wyniki leczenia 470 chorych na raka piersi napromienianych po mastektomii

\begin{tabular}{|c|c|c|c|c|}
\hline Okres przeżycia & 5-letni & 10-letni & 15-letni & 20-letni \\
\hline PB z 95\% pu & $47(43-50)$ & $32(28-36)$ & $25(21-29)$ & $19(15-23)$ \\
\hline PC z $95 \%$ pu & $61(57-65)$ & $40(36-44)$ & $33(29-37)$ & $24(20-24)$ \\
\hline
\end{tabular}

PB — przeżycie bezobjawowe; PC — przeżycie całkowite; pu — przedział ufności 
Tabela III. Czynniki prognostyczne dla przeżycia bezobjawowego PB - model proporcjonalnego ryzyka Coxa

\begin{tabular}{lcc}
\hline Czynnik prognostyczny & Wartość p & $\begin{array}{c}\text { Ryzyko } \\
\text { względne } \\
(95 \% \text { PU) }\end{array}$ \\
\hline $\begin{array}{l}\text { Typy hist.pat. carcinoma invasivum: } \\
\text { Grupa referencyjna: }\end{array}$ & & \\
$\begin{array}{l}\text { Typy dobrze rokujące } \\
\text { Carcinoma ductale }\end{array}$ & 0,05 & \\
Carcinoma lobulare & 0,07 & $1,52(0,96 ;$ \\
& & $2,40)$ \\
Liczba w/ch pN (+) & 0,02 & $1,78(1,10 ;$ \\
Grupa referencyjna: & & $2,87)$ \\
pN0 & 0,000 & \\
1-3 & & \\
& 0,19 & $1,22(0,90-$ \\
$4-8$ & & $1,66)$ \\
$\geq 9$ & 0,000 & $1,91(1,40 ;$ \\
& & $2,60)$ \\
\hline
\end{tabular}

PU - przedział ufności

\section{Dyskusja}

Wyniki leczenia chorych na raka piersi przeważnie określa się w 5-letnich okresach przeżycia, gdyż w takim właśnie czasie pojawia się od 70 do $90 \%$ niepowodzeń. W grupie analizowanych chorych, leczonych w latach 1985-1994, $86 \%$ niepowodzeń pojawiło się w ciągu 10 lat, a 14\% niepowodzeń — po 10 latach. W długoletniej obserwacji chorych stwierdzano kolejne niepowodzenia głównie w postaci przerzutów odległych, co spowodowało, że 20-letnie przeżycia całkowite wyniosły jedynie $24 \%$. Obserwacje nasze uważamy za wystarczająco długie, by rzetelnie ocenić efekty leczenia. Część autorów sądzi, że po 20 latach obserwacji nawroty raka piersi zdarzają się niesłychanie rzadko, a przewidywana długość życia jest porównywalna do populacji kobiet niechorujących na raka piersi [5]. Jednakże Brener i Hakulinen wykazali, że u kobiet, u których rak piersi rozpoznawany jest przed 50 rokiem życia, zwiększone ryzyko nawrotu raka piersi utrzymuje się nawet do 40 lat po leczeniu [6].

Przedstawiona w obecnej pracy analiza niepowodzeń z zastosowaniem metody konkurujących ryzyk pozwoliła na oszacowanie ryzyka wystąpienia niepowodzeń lokoregionalnych z uwzględnieniem udziału innych typów niepowodzeń (ryc. 3). Potwierdzono fakt, że dominującym niepowodzeniem leczenia były przerzuty odległe. Uważamy, że retrospektywna ocena tak odległych wyników leczenia jest trudna i stanowi jedynie pewne przybliżenie rzeczywistości. Obecna analiza niepowodzeń dotyczy grupy chorych leczonych na raka piersi w dawnych latach, z niedostateczną z dzisiejszego punktu widzenia diagnostyką i postępowa-
Tabela IV. Czynniki prognostyczne dla przeżycia całkowitego PC — model proporcjonalnego ryzyka Coxa

\begin{tabular}{lcc}
\hline Czynnik prognostyczny & $\begin{array}{c}\text { Wartość } \\
\mathbf{p}\end{array}$ & $\begin{array}{c}\text { Ryzyko } \\
\text { względne } \\
(95 \% \mathrm{PU})\end{array}$ \\
\hline $\begin{array}{l}\text { Pierś prawa vs lewa } \\
\text { Nipple invasion }\end{array}$ & 0,06 & $1,23(0,99 ; 1,52)$ \\
Nie vs Tak & 0,02 & $1,59(1,08 ; 2,34)$ \\
$\begin{array}{l}\text { Typy hist.pat. carcinoma invasivum: } \\
\text { Grupa referencyjna: }\end{array}$ & & \\
$\begin{array}{l}\text { Typy dobrze rokujące } \\
\text { Carcinoma ductale }\end{array}$ & 0,03 & \\
Carcinoma lobulare & 0,01 & $1,90(1,14 ; 3,17)$ \\
Liczba w/ch pN (+) & 0,00 & $2,08(1,23 ; 3,53)$ \\
Grupa referencyjna: & & \\
pN0 & 0,000 & \\
1-3 & & $1,11(0,80-1,53)$ \\
4-8 & 0,51 & $1,74(1,26 ; 2,40)$ \\
$\geq 9$ & 0,001 & $2,75(1,88 ; 4,02)$ \\
\hline PU-przedziałufności & 0,000 &
\end{tabular}

PU - przedział ufności

niem. W niniejszej pracy autorzy przyjęli stopnie zaawansowania raka piersi u analizowanych chorych zgodnie z oceną obowiązującą w czasie kwalifikacji do leczenia. Wiadomo jednak, że zjawisko migracji stopni zaawansowania utrudnia zawsze porównanie wyników leczenia chorych przed laty z wynikami współczesnymi. Zarówno 10-letni skumulowany odsetek przerzutów odległych - 36\%, jak i nawrotów lokoregionalnych - 21\%, są dość wysokie, co świadczy o małej skuteczności leczenia systemowego i miejscowego. Niedostateczne leczenie systemowe w analizowanym okresie i częste przerzuty odległe utrudniają jednak rzeczywistą ocenę skuteczności miejscowej. Lata 1985-1994 były okresem początku rozwoju leczenia systemowego w Polsce, a receptory steroidowe oznaczano sporadycznie. Stosowane programy chemioterapii nie zawierały antracyklin. Również radioterapia pooperacyjna oskarżana była o nadmierne ryzyko powikłań, co powodowało, że w wielu ośrodkach na świecie zaprzestano lub ograniczono do minimum jej stosowanie. W Zakładzie Teleradioterapii w Centrum Onkologii — Instytucie im. Marii Skłodowskiej-Curie w Warszawie na Ursynowie nie zrezygnowano z radioterapii pooperacyjnej, ale wprowadzono dwie metody opisane w poprzedniej pracy [7]. W pierwszej metodzie, używanej w mniejszych guzach (pT1, pT2), ale z przerzutami do węzłów chłonnych, stosowano napromienianie tylko na obszar węzłów chłonnych nadobojczykowo-pachowych i zamostkowych. W metodzie tej nie napromieniano elektywnie obszaru ściany klatki piersiowej, unikając ryzyka kardiotoksyczności. W drugiej metodzie, w przypadkach większych guzów (pT3), stosowano dodatkowo napromienianie ściany klatki 
piersiowej wiązką elektronów, planując leczenie w oparciu o tomografię komputerową. Nie obserwowano istotnych statystycznie różnic w częstości wznów lokoregionalnych u chorych napromienianych tymi metodami, a najczęstszą okolicą wznowy była ściana klatki piersiowej. Dopiero pod koniec lat 90., wraz z unowocześnieniem radioterapii i zmniejszeniem ryzyka powikłań, nastąpił na świecie i w Polsce renesans napromieniania pooperacyjnego chorych.

W badaniach randomizowanych potwierdzono znaczenie leczenia miejscowego i jego wpływ na poprawę przeżycia chorych. Wykazano, że zredukowanie o 10\% ryzyka wznowy lokoregionalnej w ciągu 5 lat zmniejsza ryzyko zgonu na raka piersi o 1,6\%, 3,7\% w ciągu 10 lat i 4,9\% w ciągu 15 lat, a całkowite 15-letnie przeżycia po zastosowaniu radioterapii po mastektomii u chorych z przerzutami do węzłów chłonnych pachowych wzrasta o 4,4 \% w stosunku do chorych nienapromienianych [8,9].

Dynamika progresji raka piersi zależy głównie od jego cech genetycznych, co decyduje o jego zróżnicowanym przebiegu. Określając podtyp biologiczny raka piersi, można z dużym prawdopodobieństwem przewidzieć jego sposób i dynamikę szerzenia się, a tym samym zastosować odpowiednio dobraną chemioterapię, hormonoterapię czy leczenie celowane molekularnie. U chorych, u których po operacji stwierdza się przerzuty do węzłów chłonnych regionalnych (cecha pN+), cecha ta nadal pozostaje najsilniejszym czynnikiem prognostycznym wpływającym na dobór agresywności leczenia uzupełniającego. W grupie badanych chorych w analizie wieloczynnikowej potwierdzono zależność, że im więcej jest zajętych przez przerzuty węzłów chłonnych w pasze, tym gorsze rokowanie chorych. Interesującym jest fakt, że nie wykazano różnic istotnych statystycznie w grupie chorych z pN0 vs pN1-3 zarówno we wpływie na PB, jak i na PC. Dent i Hanna wykazali, że klasyczne czynniki prognostyczne, takie jak młody wiek chorych, wielkość guza, jego złośliwość histopatologiczna, liczba zajętych węzłów chłonnych, mają większy wpływ na PB i PC u chorych w raku luminalnym niż $w$ raku nieluminalnym. W raku nieluminalnym stwierdzono, że po 10 latach obserwacji chorych nie wielkość guza, a tylko liczba zajętych węzłów chłonnych była czynnikiem prognostycznym, wpływającym na PB i PC [10]. Fakty te $w$ dzisiejszych czasach determinują inny sposób leczenia chorych w różnych podtypach biologicznych raka piersi.

Do najpoważniejszych powikłań późnych związanych $z$ radioterapią po mastektomii radykalnej należą: obrzęk kończyny górnej, porażenie splotu barkowego, kardiotoksyczność i zwłóknienia popromienne płuc, zespół BOOP (Bronchiolitis Obliterans Organizing Pneumonia) i nowotwory wtórne. Częstość obrzęku kończyny górnej zależy od agresywności leczenia chirurgicznego w jamie pachowej. Radioterapia pooperacyjna obszaru pachy po radykalnej limfadenektomii zwiększa prawie dwukrotnie ryzyko obrzę- ku kończyny górnej. Ryzyko powikłań zwiększa się w miarę rozszerzania pól, podwyższania lub nakładania się dawek radioterapii. W analizowanej grupie chorych częstość obrzęku kończyny górnej obserwowano u 13,6\%, a porażenie splotu barkowego u $0,9 \%$ chorych, co jest zgodne z danymi z piśmiennictwa [11, 12]. Autorzy zdają sobie sprawę z braków informacji w analizowanej grupie chorych dotyczących późnych powikłań, jednakże z uwagi na fakt, że leczenie napromienianiem i obserwacja chorych były prowadzone w jednym ośrodku i przez jeden zespół lekarzy, należy przypuszczać, że obserwowane wyniki są wiarygodne.

Nie obserwowano późnych klinicznych objawów kardiotoksyczności i duszności, będących następstwem zmian popromiennych w sercu i płucach, co może przemawiać za bepieczeństwem stosowanej techniki radioterapii. Jednakże nie prowadzono prospektywnych badań kardiologicznych, a przyczyny zgonu u 54 (11,5\%) chorych nie udało się ustalić. Prawdopodobnie część tych chorych zmarła z przyczyn naturalnych, gdyż ich średni wiek w momencie zgonu wynosił 71 lat, a więc był zbliżony do średniej długości życia kobiet w tym okresie w Polsce. Obecnie uważa się, że stosowanie nowoczesnego planowania i komputerowych technik radioterapii zmniejsza do minimum objawy popromienne w płucach i sercu [13].

Henson i wsp. badali, czy chore otrzymujące radioterapię z powodu raka lewej piersi mają większe ryzyko zgonu z powodu kardiotoksyczności i czy częściej u chorych napromienianych występuje rak płuca. W tym celu z największego amerykańskiego rejestru epidemiologicznego SEER wykorzystano dane około 560000 chorych na wczesnego raka piersi, leczonych w latach 1973-2008. Połowa chorych była napromieniana pooperacyjnie. Okazało się, że jedynie chore napromieniane na ścianę klatki piersiowej po stronie lewej w dawnych latach (do 1982 r.) miały zwiększone ryzyko zgonu z powodu kardiotoksyczności w stosunku do chorych napromienianych na stronę prawą. Ryzyko to zwiększało się wraz z okresem obserwacji odpowiednio: w pierwszej dekadzie, od 10 do 14 lat, od 15 do 19 i powyżej 20 lat. Odpowiednie ryzyka względne przy 95-procentowym przedziale ufności wynosiły: 1,19 (1,03-1,38); 1,35 (1,05-1,73); 1,64 (1,26-2,14); $1,90(1,52-2,37), p<0,001$. Badacze ci stwierdzili również częstsze zgony chorych z powodu raka płuca po stronie napromienianej niż nienapromienianej. Zgony te występowały w drugiej i trzeciej dekadzie po radioterapii z powodu raka piersi. Odpowiednie ryzyka względne przy 95-procentowym przedziale ufności wynosiły: 2,04 (1,28-3,23) i 3,87 (2,19-6,82) $-2 p=0,002$ [14]. Jednym z najpoważniejszych powikłań po radioterapii pooperacyjnej są mięsaki popromienne. Częstość ich jest bardzo rzadka: około 1\% [15]. W naszym materiale nie obserwowaliśmy mięsaków popromiennych, natomiast u jednej chorej rozpoznano, w obszarze spadku dawki, płaskonabłonkowego raka płuca. 


\section{Wnioski}

1. Uzyskane odległe wyniki leczenia chorych na raka piersi napromienianych po mastektomii (dwudziestoletnie PB, PC i SRNLR odpowiednio: 19\%, 24\% i 21\%) świadczą, z dzisiejszego punktu widzenia, o małej skuteczności ówczesnego leczenia.

2. Po mastektomii radykalnej najsilniejszym negatywnym czynnikiem wpływającym zarówno na ryzyko nawrotu raka piersi, jak i zgonu z powodu raka piersi jest większa od trzech liczba zajętych przez przerzuty węzłów chłonnych pachowych.

3. Pięcioletni okres obserwacji chorych na raka piersi jest zbyt krótki do oceny wyników leczenia, gdyż nawet po 10 latach ryzyko nawrotu lub zgonu z powodu raka piersi jest wysokie - w analizowanej grupie chorych było ocenione na $14 \%$.

\section{Konflikt interesu: nie zgłoszono}

\section{Dr n. med. Jacek Gałecki}

Zakład Teleradioterapii

Centrum Onkologii - Instytut

im. Marii Skłodowskiej-Curie

ul. Roentgena 5, 02-781 Warszawa

e-mail:jacekg@coi.waw.pl

Otrzymano: 12 listopada $2013 \mathrm{r}$.

Przyjęto do druku: 25 lutego 2014 r.

\section{Piśmiennictwo}

1. Wojciechowska U, Didkowska J, ZatońskiW. Nowotworyzłośliwe w Polsce w 2010 r. Centrum Onkologii — Instytut im. Marii Skłodowskiej-Curie, Krajowy Rejestr Nowotworów, Warszawa 2012.
2. Didkowska J, Wojciechowska U. Nowotwory piersi w Polsce i Europie — populacyjny punkt widzenia. Nowotwory JOnco/ 2013;63:111-118.

3. Arriagada R, Rutqvist LE, Kramar A i wsp. Competing risks determining event-free survival in early breast cancer. Br J Cancer 1992; 66: 951-957.

4. Karlsson P, Cole BF, Price KN i wsp. The role of the number of uninvolved lymph nodes in predicting locoregional recurrence in breast cancer. J Clin Oncol 2007; 25: 2019-2026.

5. Louwman WJ, Klokman WJ, Coebergh JW. Excess mortality from breast cancer 20 years after diagnosis when life expectancy is normal. B J Cancer 2001; 84: 700-703.

6. Brenner $\mathrm{H}$, Hakulinen $\mathrm{T}$. Are patients diagnosed with breast cancer before age 50 years ever cured? J Clin Oncol 2004; 22: 432-438.

7. Gałecki J, Grudzień-Kowalska M, Załucki i wsp. Results of adjuvant therapy in postmastectomy breast cancer patients irradiated at the Maria Skłodowska-Curie Memorial Cancer Center and Institute of Oncology in Warsaw between 1985 and 1994. Nowotwory J Oncol 2004; 54: 219-229.

8. Clarke M, Collins R, Darby Si wsp. Effects of radiotherapy and of differences in the extent of surgery for early breast cancer on local recurrence and 15-year survival: an overview of the randomised trials. Lancet 2005; 366: 2087-2106.

9. Punglia RS, Morrow M, Winer EP, Harris JR. Local therapy and survival in breast cancer. N Engl J Med 2007; 356: 2399-2405.

10. Dent R, Hanna WM, Trudeau M i wsp. Time to disease recurrence in basal-type breast cancers: effects of tumor size and lymph node status. Cancer 2009; 115: 4917-4923.

11. Moran MS, Haffty BG. Radiation techniques and toxicities for locally advanced breast cancer. Semin Radiat Oncol 2009; 19: 244-255.

12. Gałecki J, Hicer-Grzenkowicz J, Grudzień-Kowalska M i wsp. Radiation-induced brachial plexopathy and hypofractionated regimens in adjuvant irradiation of patients with breast cancer-a review. Acta Oncologica 2006; 45: 280-284.

13. Prosnitz LR, Marks LB. Postmastectomy radiotherapy: quality counts! J National Cancer Inst 2006; 98: 3-4.

14. Henson KE, McGale P, Taylor C, Darby SC. Radiation-related mortality from heart disease and lung cancer more than 20 years after radiotherapy for breast cancer. br J Cancer 2013; 108: 179-182. doi:10.1038/bjc.2012.575.

15. Erel E, Vlachou E, Athanasiadou M i wsp. Management of radiation-induced sarcomas in a tertiary referral centre: a review of 25 cases. The Breast 2010; 19: 424-427. doi:10.1016/j.breast.2010.04.006. 